\title{
Study of Population Growth and Land Use Change Impact of Intrusion at Pekalongan City
}

\author{
Erni Suharini \\ Department of Geography \\ Social Science Faculty, Semarang State University \\ Indonesia \\ Coresponding email: ernisuharini@gmail.com \\ Fahrudin Hanafi \\ Department of Geography \\ Social Science Faculty, Semarang State University \\ Indonesia \\ Wahid Akhsin Budi Nur Sidiq \\ Department of Geography \\ Social Science Faculty, Semarang State University \\ Indonesia
}

\begin{abstract}
The research objective is to find a relation between population growths, land use change of Pekalongan City. Research location based on administrative boundary, which divided into coastal and non-coastal. Data series calculated from 2000-2015 as input correlation. Land use series data derived from Google earth data and Spot 5, also population growth based on literacy. Grid systemic used as sampling method. Land use derived using interpretation and accuracy result is $85,74 \%$. Land uses at Pekalongan City on 2015 are elaborate as follows; building, open field and water body. Analysis data showed, especially built area growth $5,08 \mathrm{ha}$ per year. Based on population growth analyst of Pekalongan City from 2000-2015 showed 7,3\% growth or 0,76 years. Population growth simulation on 2035 is 956.638 inhabitants, or 9,46 in 20 years. Meanwhile, with historical analysis, land use can be simulated to 2035 using Land use Sim and ArcGIS. Built area growth simulate in two scenarios. First use a linear growth, second using population growth correlations. The first scenario built area growth total $29,34 \mathrm{~km}^{2}$, and second $27,18 \mathrm{~km}^{2}$. The impact of land use change and population growth is an intrusion. Based on laboratory tests show that Pekalongan city intrusion on high category. The region within distance $500-600 \mathrm{~m}$ from the coastline has salinity level of 6,7 to $15.5 \%, 800-900 \mathrm{~m}$ has a salinity level of 2,9 to $6.6 \%$, 1 $1.5 \mathrm{~km}$ has a salinity level of 1,4 to 2,8 . Conclusion, land use change on Pekalongan City rather high, especially shrub, and dry agriculture changes into a settlement and built area. Furthermore, the coefficient correlation between population and built area is high $(0,93)$. These include a significant difference final result of simulation using Landuse Sim with linear approach and consider the expense of population growth influence. Furthermore, land use change on Pekalongan city drives an environmental problem, for instance intrusion.
\end{abstract}

Keywords—Land use change, population growth, intrusion

\section{INTRODUCTION}

Ecologically coastal region is an area of transition between sea and land, inland covers areas that are affected by the splash of the sea or tidal water, and towards the sea covering the continental shelf area (Dahuri, 2001).

Coast as a spatial resource is has a great potential as the development center. Within coast, full of biotic, and abiotic resource to support regional development and self-sustain economic activity. Pekalongan City which located on North Sea coastal area, grown like other coastal city with its own problem. For instance socio-economic problem, squatter, environmental problem, water quality degradation, and batik waste which caused of population growth.

Pekalongan city is located on the north coast of Central Java with the rapid development progress. The high number of residents in this region concomitant with the need for fresh and clean water for domestic use. Resident using a common well to meet its needs by considering cheaper than water company. On 2004 only $24 \%$ of the total need of clean water that can be supplied from river water, while $76 \%$ supplied from groundwater by local residents and PDAM (Hamam, et.al, 2004).

Pekalongan coastal city even though include on Central Java spatial plan as a center activity and well planned, it's impaired a basic environment phenomenon such as tidal flood, land subsidence, and saline intrusion. Saline water is the most common problem of water quality in the coastal city, especially on developing country such as Indonesia.

Groundwater is part of water in nature that is below ground level. Formation of groundwater following the circulation cycle of the water on earth is called the hydrologic cycle, which is a natural process that takes place on the water in nature are experiencing displacement sequentially and continuously (Kodoatie, 2012).

Exploitation of groundwater resource, include coastal aquifers on massively and continuous will decrease the volume of fresh water into the ocean, include of groundwater interface 
pressure. This condition can disrupt hydrological balance, because balance only can occur when the propulsion water is proportional to the number of potential gravitational force and the suction power potential, so the higher the position of the surface of the ground water potential suction force becomes smaller (Asdak, 2010).

When fresh water aquifer in empty or lower condition may causing intrusion. Saline water on aquifer may derived from several sources; 1) encroachment of sea water in coastal area, 2) sea water that entered aquifers in past geologic time, 3) salt on dome, thin bed, or disseminated in geologic formation, water concentrated by evaporation in tidal lagoon, or other enclosed area, 5) return flow to stream from irrigated lands, 6) human activity. (Todd, 1980)

The mechanism of saline water intrusion divided into three categories (Todd, 1980):

- Related the reduction or reversal of groundwater gradients. This condition related with hydraulic response of wells pumping near the ocean for hydrodynamic balance.

- Generate from destruction event of the natural barrier which divide/ separate fresh water and saline water. Ex: canaling that enables tidal water to advance and percolate fresh water.

- Occurs when subsurface disposal with saline water, ex: landfill, or water repositories.

According to Lubis (2006) where groundwater is largely controlled by the history and geologic condition, delineation and boundary conditions of soil and rock formations in a region experiencing water percolation.

The research objective is to study population growth and land use change impact of intrusion on Pekalongan city.

\section{METHOD}

The study was conducted in the coastal region of Pekalongan city, especially in North Pekalongan District. This research was conducted in order to determine the level of intrusion as a result of land use changes in $2005-2015$. This research using primary and secondary data as input.

Secondary data, using public or government publications, among others Pekalongan City On Number publicized by Statistical Central Bureau to obtain demographic data from the $2005-2015$.

The methodologies of primary data on this research are:

A. Field Survey, conducted measurements to each sample point that has been determined include water surface level, depth, and water sampling. Each public wells or ponds taking water samples to be conducted on laboratory tests to determine the salinity level. Salinity level derived from chemical analysis using argentometry titration. Argentometry deposition method used, because it's requires the establishment of relatively insoluble compounds.
B. Satellite Image Interpretation on 2005-2015 data with a visual method to obtain land use data at several years, as spatial analysis input on land use change in Pekalongan City. Satellite imagery used is Google Earth on 2005, SPOT 5 on 2015. Radiometric, and spatial correction using ERMapper to preserve data obtain for validity. (Parman, 2010).

C. Interview using a questionnaire on the local community to obtain data series of groundwater conditions; include the response and communities adaptation to deal with intrusion phenomenon of the study area.

Sample location carried out by stratified grid sampling method and field units. This sampling method divides the population by groups with a uniform hierarchy balanced or equal degree (Ebdon, 1985).

Stratified and grid sampling is used to divide Pekalongan city into several zones, namely the coastal, coastal alluvial, and alluvial plains. A grid pattern composed stretches from east to west into 5 pieces grid, as well as some additional samples at the river and sea as a comparison.

The sample locations show the following figure.
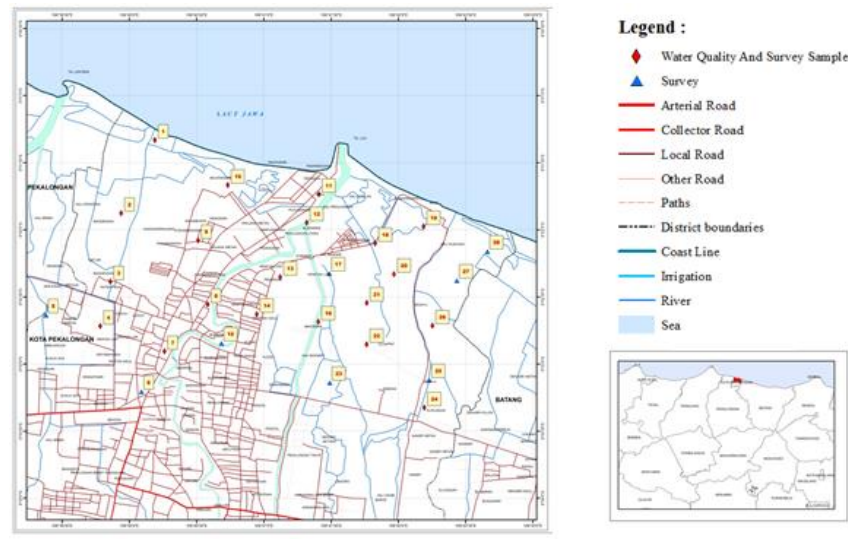

Fig.1. Sample Location on Pekalongan City

Land use change analysis using spatial analyst and overlay method (geo-processing) of ArcGIS 10.4 tool. Land use data obtained from remote sensing data as input of simulation analysis, include population growth simulation to 2035 .

Population growth simulation using arithmetic model, meanwhile land use change simulation using Land Use SIM Software. This software is GIS raster based and MarkovCellular Automata, AHP (Analytical Hierarchical Process) combining Fuzzy set to preserve artificial movement of land use changes. (Pratomoatmojo, N.A., 2012). 


\section{FINDING AND DISCUSSION}

\section{A. Land Use Change and Simulation}

Land use in the study area is arranged in 2005-2015 periods, so that it can be used to determine the changes that occur and used as a benchmark for predicting for the next few years. Based on the interpretation results, land use of study area are classified into 21 classes. However, to simplify changes analysis that occurred, land use classes generalized into 3 classes on developed area, undeveloped, open land and water body.

Analysis result shows that from 2005- 2015 land use changed. Especially on develop area of 25.42 ha, meanwhile, water body and an open land decrease of 39.82 ha and 85.60 ha. Increased of built or developed area because the conversion of open land which consisting of convulsions, mix plantations, fallow land and fields indirectly due to population growth in the study area.

Prediction land use changes using spatial model based on the tendency changes that occur over time in the method of Cellular Automata (CA). CA is a spatial modeling based which able to predict conditions in the future with local interactions between cells in a regular grid (Agustiono et al, 2014), in which the cells will present land use. CA consists of several components, among other pixels, nearest neighborhood and transition rules.

Modeling Processes is using Landuse Sim 2.0 software. Landuse Sim is a simulation based software and spatial grid modeling with raster data as a land use spatial attributes. Land use modeling at the Pekalongan City consider a nearest neighbor and buffer analysis of various influencing factors that are distant to roads, distant to activities center and distant of existing settlements.

Land use changes simulation made up to 2035 with 5-years intervals, so results will be generated predictive modeling land use maps in 2020, 2025, 2030 and 2035. Comparison of the extended land use predictions presented in Table 1 . While spatial patterns of complete prediction land use results shown in Figure 2.

TABLE 1. LAND USE COMPARISON OF IN PEKALONGAN ON 2005 - 2035

\begin{tabular}{|c|l|c|c|c|c|c|c|}
\hline \multirow{2}{*}{ No. } & \multirow{2}{*}{ Land Use Class } & \multicolumn{5}{|c|}{ Years (ha) } \\
\cline { 3 - 8 } & & 2005 & 2015 & 2020 & 2025 & 2030 & 2035 \\
\hline 1 & Built Area & $2.074,17$ & $2.099,59$ & $2.603,51$ & $2.713,52$ & $2.823,75$ & $2.933,68$ \\
\hline 2 & Open Field & $2.182,71$ & $2.097,11$ & $1.669,88$ & $1.559,87$ & $1.449,60$ & $1.339,55$ \\
\hline 3 & Water Body & 302,06 & 262,24 & 373,97 & 373.99 & 374,04 & 374,04 \\
\hline & & $4.558,95$ & $4.558,95$ & $4.558,95$ & $4.558,95$ & $4.558,95$ & $4.558,95$ \\
\hline
\end{tabular}

Source : Analysis Result, 2016

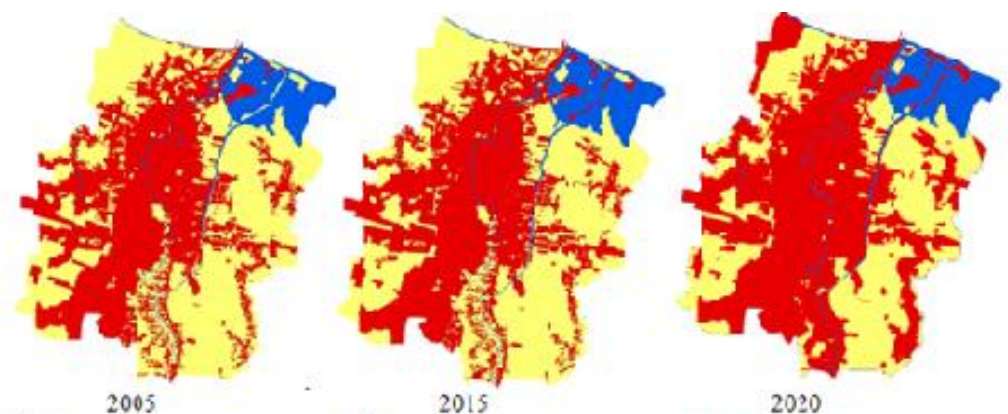

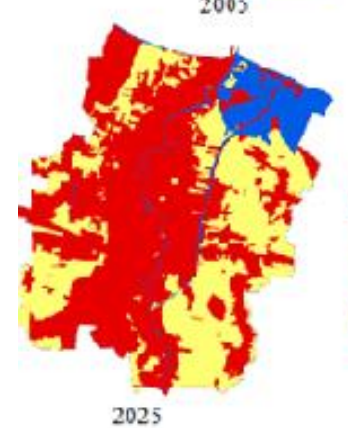

2025

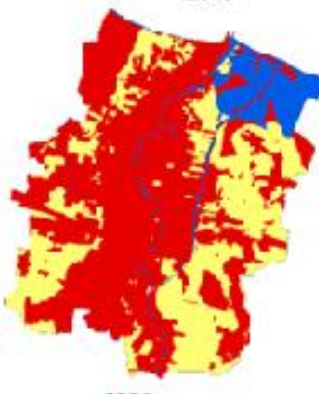

$203 \mathrm{C}$

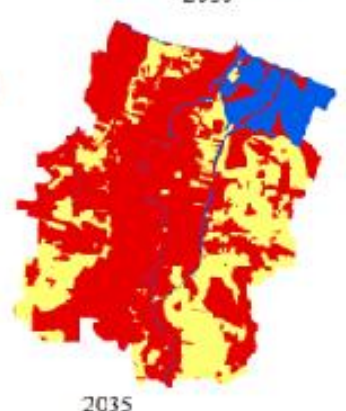

2035

\section{LEGEND}

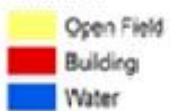

Fig 2. Land use change and simulation model 
Land use modeling using three constraints as a limitation, which is fuzzy map of distant road, activity center, and exist settlement. Other input is pixel growth, which calculated from land use growth of 2005-2015, and projected on linear growth combining population growth on 2015-2035. Population growth in 20 years, are $9,46 \%$ or about 873.972 people on 2015 to 956.638 people on 2035 .

Exponentially growth of 5 years about 109.93 Ha. This vast increase occurred mostly in coastal areas of Pekalongan. Focused simulate land use are developed/ built area, open field, and water body. The figure below shows population growth and simulation of Pekalongan City on 2010-2035.

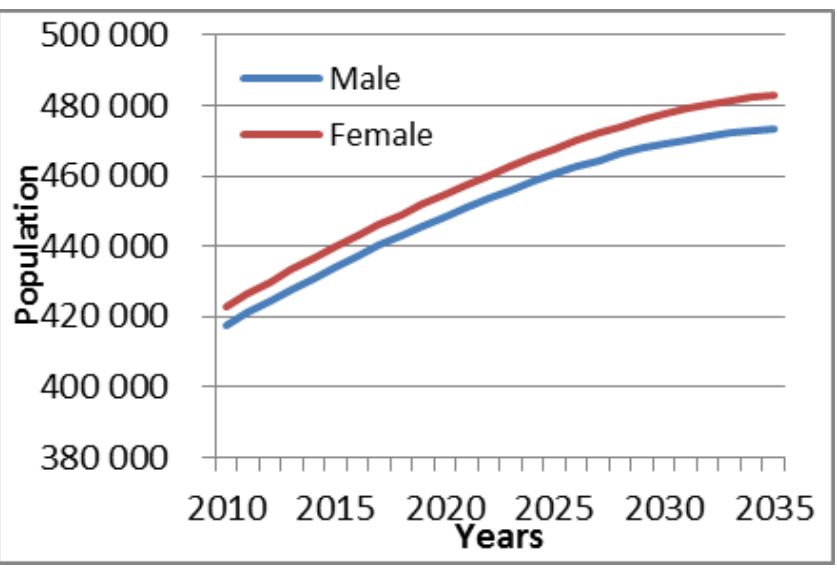

Fig. 3. Population growth and simulation

Land use change and population growth correlation power about 0,95 . Land use change and simulation on 2005-2035 shows the following figure.

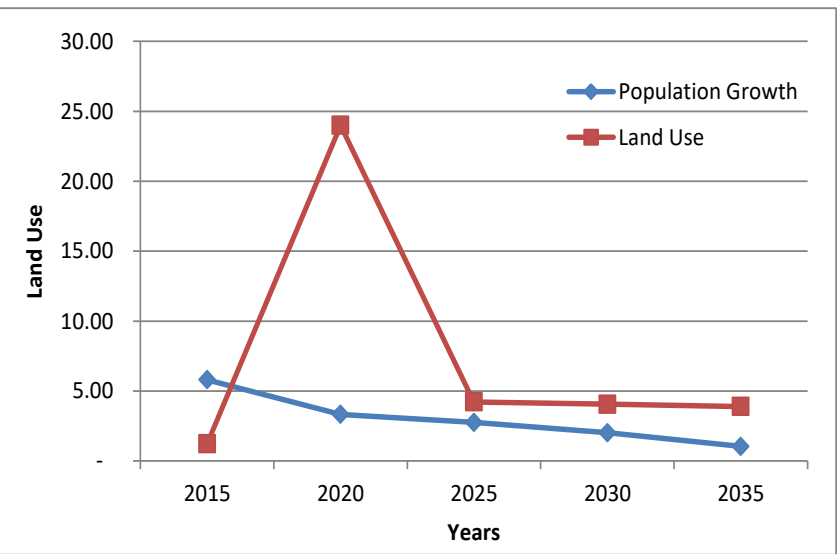

Fig. 4. Population Growth and Land Use Change Comparison

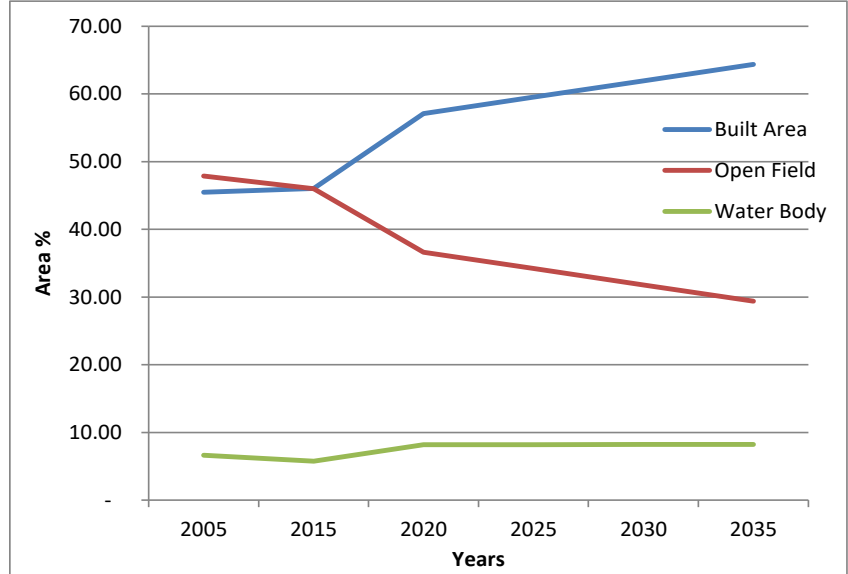

Fig. 5. Land Use Change Existing and Simulation 2005-2035

B. Groundwater Level

Pekalongan City water table or ground water depth which represented with well and river depth obtained from field survey by measuring sampled residents about 23 sample. Furthermore, to determine flow net and spatial pattern data, the survey data interpolated using Inverse Distance Weight (IDW) with power value 2 .

The following Table described that groundwater levels at Pekalongan City between 0.42 to 1.74 meters below topographic surface. The deepest is located in the Sampangan Village or at central of Pekalongan with $3.23 \mathrm{~km}$ distance of the coastline. While the shallowest location located at $0.43 \mathrm{~km}$ of coastline.

TABLE 2. GROUNDWATER DEPTH SAMPLED ON PEKALONGAN CITY

\begin{tabular}{|c|c|c|c|}
\hline \multirow[b]{2}{*}{ No. } & \multicolumn{2}{|c|}{ Sample Location Coordinate } & \multirow{2}{*}{$\begin{array}{c}\text { Depth } \\
\text { (Meter Below } \\
\text { Surface) } \\
\end{array}$} \\
\hline & $\mathbf{X}$ & $\mathbf{Y}$ & \\
\hline 1 & 353670 & 9241455 & 0,70 \\
\hline 2 & 353065 & 9240557 & 1,00 \\
\hline 3 & 352531 & 9239894 & 0,86 \\
\hline 4 & 352223 & 9239570 & 0,70 \\
\hline 5 & 351524 & 9239582 & 0,75 \\
\hline 6 & 352823 & 9238547 & 1,07 \\
\hline 7 & 353707 & 9239875 & 1,00 \\
\hline 8 & 353606 & 9240668 & 0,55 \\
\hline 9 & 353619 & 9240644 & 0,42 \\
\hline 10 & 355206 & 9241330 & 0,55 \\
\hline 11 & 354656 & 9240214 & 0,98 \\
\hline 12 & 354442 & 9239547 & 0,60 \\
\hline 13 & 353817 & 9239249 & 0,17 \\
\hline 14 & 355508 & 9240424 & 0,50 \\
\hline 15 & 355622 & 9240834 & 1,11 \\
\hline 16 & 355982 & 9239458 & 0,74 \\
\hline 17 & 356340 & 9238997 & 0,61 \\
\hline 18 & 355202 & 9238433 & 1,74 \\
\hline 19 & 356615 & 9238343 & 1,45 \\
\hline 20 & 356702 & 9238747 & 0,90 \\
\hline 21 & 356639 & 9239129 & 0,97 \\
\hline 22 & 357166 & 9240099 & 0,64 \\
\hline 23 & 357233 & 9240829 & 0,75 \\
\hline
\end{tabular}


Interpolation result described that area with 0-500 meters of coastline distant have 0,56 meters groundwater depth, 501 meters-1,200 meters of coastline distant have 0.57-1 meter groundwater depth, $1,891 \mathrm{~km}$ of coastline distant have water depth $1.22-1.40$ meters groundwater depth and $3.5 \mathrm{~km}$ of coastline distant have 1,50-1,70 meters groundwater depth.

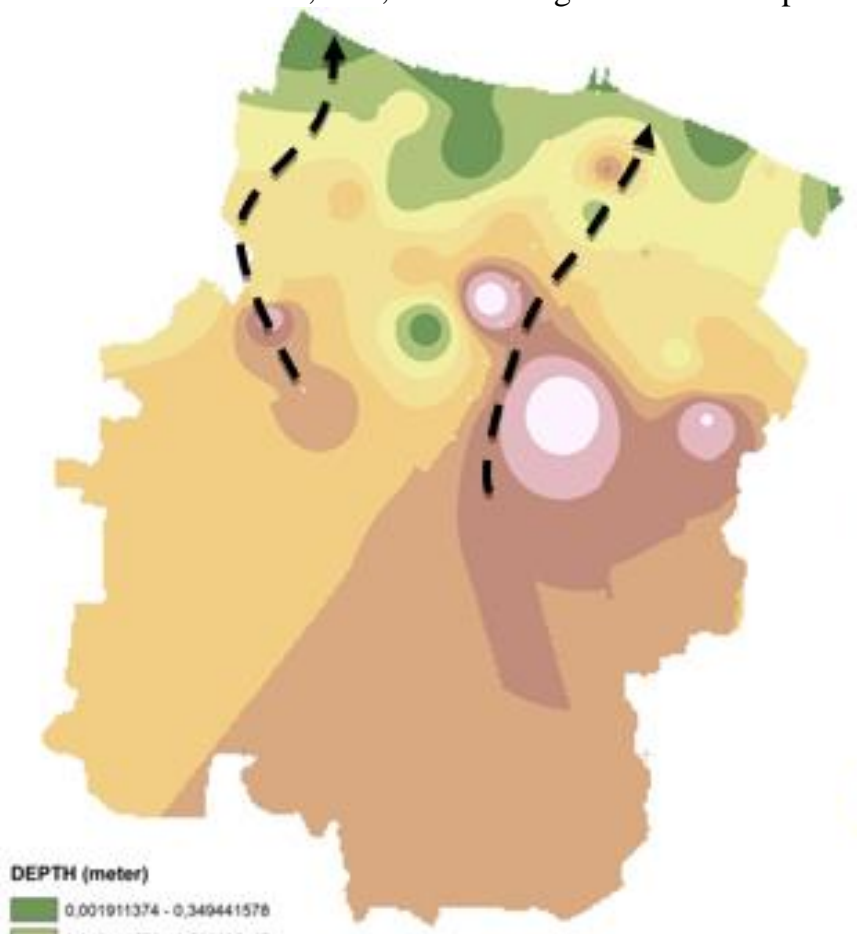

These conclude that more farther the distance from the coastline groundwater level deepen.

The following figure presents flow net and land use in Pekalongan City 2015.
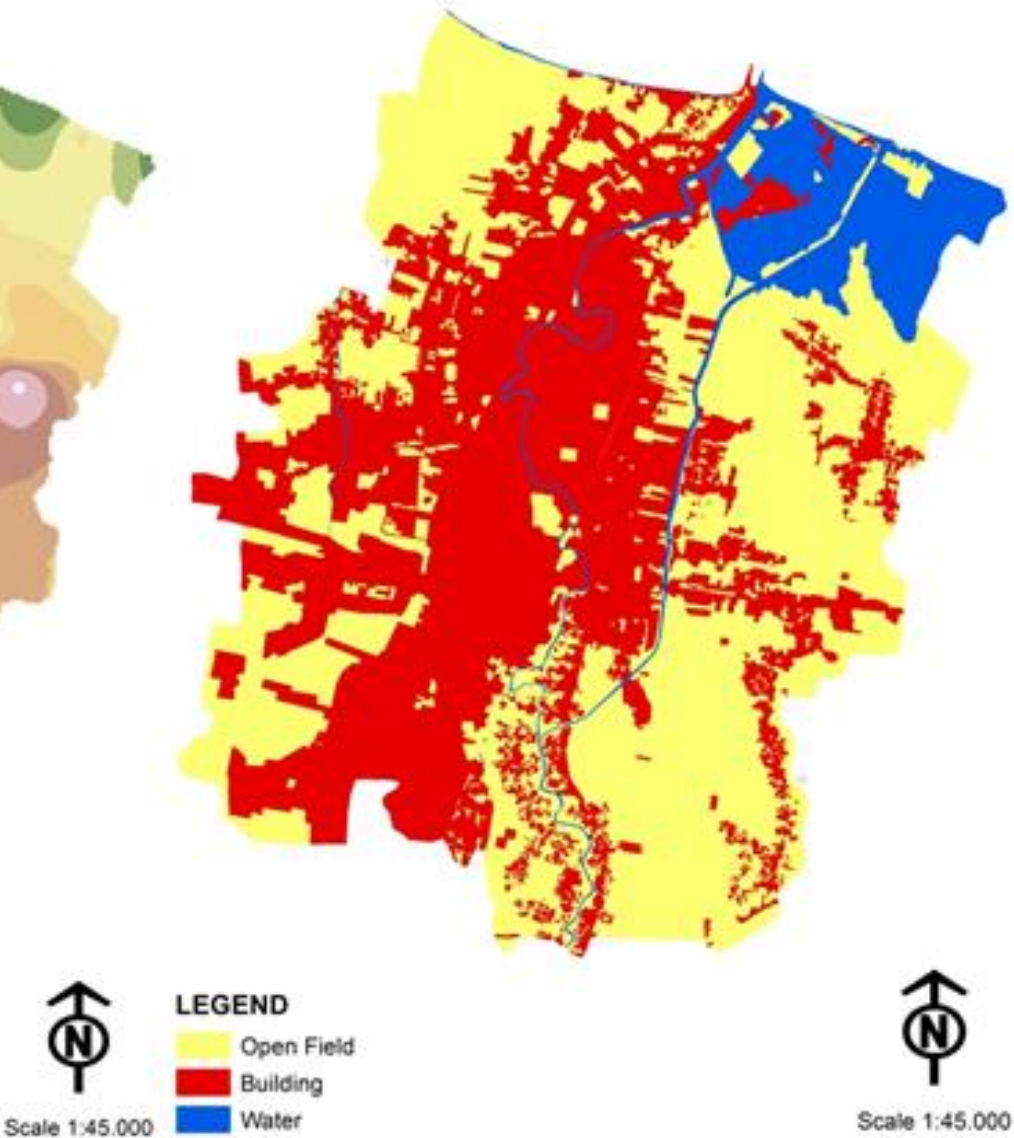

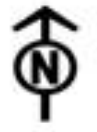

Scale 1:45.000

Fig. 6. Flownet at Pekalongan City (Left), Land Use at Pekalongan 2015 (Right)

\section{Intrusion}

The intrusion of salinity water at Pekalongan City was obtained from laboratory tests results on water samples which were taken from wells and rivers. 16 samples take spread evenly of Pekalongan coastal city. Furthermore in order to obtain the distribution of salinity, from each sample salinity level was interpolated using Inverse Distance Weight (IDW) with power 2 .

Based on salinity level, it can be described that the range of water salinity level samples from 0.20 to $12.35 \%$. The highest salinity located in the Panjang Wetan Village within 725 meters distant of the shoreline, while the lowest salinity found and located in the Klego Village within 2,756 meters from the coastline.

The following table presents the salinity level each sample.

TABLE 3. SALINITY LABORATORY RESULT

\begin{tabular}{|c|c|c|c|}
\hline \multirow{2}{*}{ No. } & \multicolumn{2}{|c|}{ Sample Coordinate } & \multirow{2}{*}{ Salinity $(\boldsymbol{\%})$} \\
\cline { 2 - 3 } & $\mathbf{X}$ & $\mathbf{Y}$ & 4,76 \\
\hline 1 & 353670 & 9241455 & 1,44 \\
\hline 2 & 353065 & 9240557 & 1,22 \\
\hline 3 & 352531 & 9239894 & 3,41 \\
\hline 4 & 352223 & 9239570 & 0,20 \\
\hline 5 & 352247 & 9239399 & 1,96 \\
\hline 6 & 353707 & 9239875 & 1,52 \\
\hline 7 & 353606 & 9240668 & 1,37 \\
\hline 8 & 353619 & 9240644 & 3,59 \\
\hline 9 & 355206 & 9241330 & 1,27 \\
\hline 10 & 354656 & 9240214 & 0,27 \\
\hline 11 & 354442 & 9239547 & 12,35 \\
\hline 12 & 355622 & 9240834 & 1,95 \\
\hline 13 & 355982 & 9239458 & 0,74 \\
\hline 14 & 356340 & 9238997 & 0,20 \\
\hline 15 & 356615 & 9238343 & 0,96 \\
\hline 16 & 356639 & 9239129 & 2016 \\
\hline
\end{tabular}


Based on salinity maps following figure can be concluded that intrusion by saline water occurred along the of Kota Pekalongan coastal.

This can be seen from contained salinity level, which the region within distance 500-600 meters from the coastline has salinity level of 6,7 to $15.5 \%$, an area within distance of 800 900 meters from the coastline has a salinity level 2,9 to $6.6 \%$, an area within distance $1-1.5 \mathrm{~km}$ from coastline has a salinity level 1,4 to 2,8 . Highest salinity level mostly located in the Long Wetan Village, Krapyak Kidul Village and Kandang Panjang Village.

Those region dominated by built/developed area (residential, industrial, government offices and other). Following figure describe salinity level and land use on 2015 in Pekalongan City.
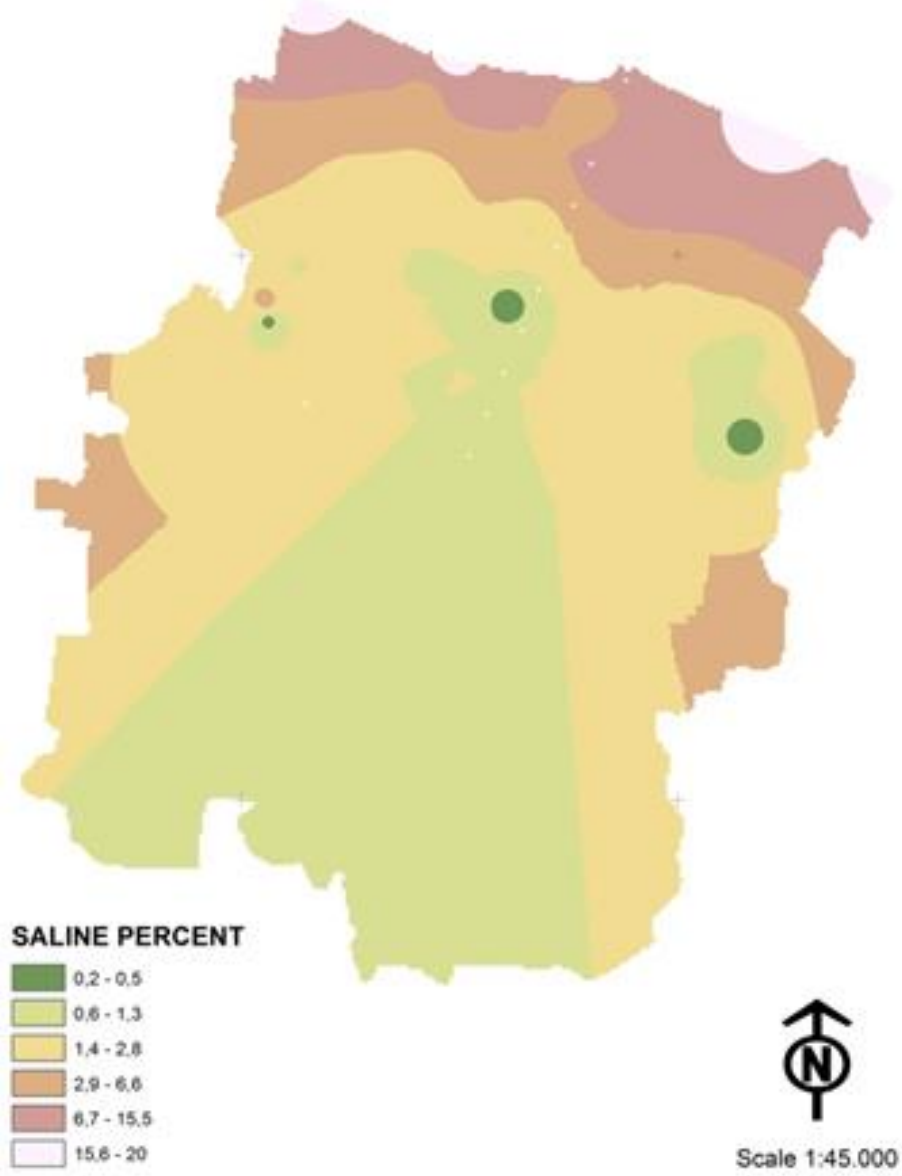

Fig. 7. The salinity level of Pekalongan City (left), Land Use 2015 in Pekalongan City (right)

TABLE 4. SALINITY LEVEL AND INTRUSION RELATIONSHIP

\begin{tabular}{|c|c|}
\hline $\mathbf{R}$ & Intrusion Level \\
\hline$<0,5$ & Fresh Water \\
$0,5-1,3$ & Small Intrusion \\
$1,3-2,8$ & Moderate Intrusion \\
$2,8-6,6$ & Rather High Intrusion \\
$6,6-15,5$ & High Intrusion \\
$15,5-20,0$ & Sea Water \\
\hline
\end{tabular}

According to the table before, showed that Pekalongan coastal city intrusion by sea water on the north part, along with the coastline sequentially on high, rather high, moderate, and small level intrusion. On this condition, at high and rather high salinity level of residential well inconsumable.
These conditions are changed from 2004 that Pekalongan city on Dukuh, south Krapyak until south Dehayu village have fresh water (DHL $<1500 \mu \mathrm{S} / \mathrm{cm}$ ), and Bandengan, Kandang Panjang, east Panjang, north Krapyak, Degayu village have rather saline with $1500(\mu \mathrm{S} / \mathrm{cm}-2.200 \mu \mathrm{S} / \mathrm{cm})$. (Hamam, 2004) The same condition has found on 2006. (Widada, 2006)

Referring to the comparison between land use 2015, flow net map and salinity interpolation, that there is a relationship between groundwater pumped by industry and intrusion of sea water. A bit difficult to compare the pattern of its spread without adding geoelectric profile data and amount of water pumped from tax data of energy mineral resources authority. 
It concludes that the presence of sea water intrusion is a problem in the groundwater utilization in the coastal areas, because it impacts directly on the groundwater quality. (Hendrayana, 2002)

When this happens constantly, in the long term will generate new problems such as groundwater level decline, water quality groundwater degradation, and land subsidence. (Hendrayana, 2002)

\section{CONCLUSION AND SUGGESTION}

The results of this study indicate that in period 2005-2015 seawater intrusion increased either spatially or salinity level. There is a relationship between the population growth, land use changes, groundwater depth changes and salinity level changes, although not spatially measured. Land use Sim can be used to simulate land use change, and help to projected changes in net flow or salinity map.

In the future, need to complete this research, especially the geo-electric data, groundwater profile, distribution of pumped deep wells. Further research can be simulated on threedimensional profiles the effect of land use changes on the intrusion of Pekalongan City.

\section{REFERENCES}

[1] Agustiono, A., Sitorus, S.R. and Kartodihardjo, H., 2014. Kajian Perubahan Penggunaan Lahan Untuk Arahan Penataan Pola Ruang Kawasan Hutan Produksi Gedong Wani, Provinsi Lampung. Majalah Ilmiah Globe, 16(1).

[2] Dahuri, R, Rais, J., Ginting, SP., dan Sitepu, MJ. 2001. Pengelolaan Sumber Daya Wilayah Pesisir dan Lautan.

[3] Ebdon, David,1985, "Statistics In Geography-Second Edition", Blackwell Publishers Ltd

[4] Hamam, Dkk, 2004, Kerusakan Akibat Intrusi Air Laut Di Pantai Utara Jawa Tengah, Badan Penelitian dan Pengembangan Provinsi Jawa Tengah

[5] Hendrayana, H, 2002, Intrusi Air Asin Ke Dalam Akuifer di Daratan, Geological Engineering Dept., Faculty of Engineering, Gadjah Mada University, UGM ñ Yogyakarta.

[6] Kodoatie, J.K, 2013, Tata Ruang Air Tanah, Andy, Yogyakarta.

[7] Lubis, RF. 2006. Bagaimana Menentukan Daerah Resapan Air Tanah. Graduate School of Science and Technology. Chiba University, Japan. Inovasi Journal Vol. 6.

[8] Pratomoatmojo, N.A., 2012. Land Use Change Modelling Under Tidal Flood Scenario By Means Of Markov-Cellular Automata In Pekalongan Municipal (Doctoral dissertation, Universitas Gadjah Mada).

[9] Parman, S., 2010. Deteksi Perubahan Garis Pantai Melalui Citra Penginderaan Jauh Di Pantai Utara Semarang Demak. Jurnal Geografi, 7(1).

[10] Todd, David Keith, 1980, Groundwater Hydrology-Second Edition, University Of California, John Wiley and Son

[11] Widada, S., 2010. Gejala Intrusi Air Laut di Daerah Pantai Kota Pekalongan. ILMU KELAUTAN: Indonesian Journal of Marine Sciences, 12(1), pp.45-52. 